The IJA is a peer-reviewed open-access, electronic journal, freely available without charge to users

\title{
Improved reproductive performance of captive male broodstock of tiger shrimp Penaeus monodon with 17a-methyltestosterone induction
}

\author{
Rosmiati Rosmiati ${ }^{*}$, Andi Parenrengi ${ }^{1}$, Emma Suryati ${ }^{1}$, Samuel \\ Lante $^{1}$, Harlina Harlina ${ }^{2}$, Andi Tenriulo' ${ }^{1}$, Sahabuddin Sahabuddin ${ }^{1}$ \\ ${ }^{1}$ Research Institute for Coastal Aquaculture and Fisheries Extension, Maros-90512, South \\ Sulawesi, Indonesia \\ 2 Department of Fisheries Aquaculture, Faculty of Fishery and Marine Science, Makassar- \\ 90231, Universitas Muslim Indonesia, South Sulawesi, Indonesia
}

Key words: 17a-Methyltestosterone, Penaeus monodon, Reproductive performance, Spermatophore quality, Hatching rate

\begin{abstract}
The purpose of this study was to evaluate the influence of different 17amethyltestosterone injection frequencies at optimal doses to improve the quality of spermatophore and reproductive performance of captive male broodstock of tiger shrimp Penaeus monodon. Broodstocks of tiger shrimp weighing $51-65 \mathrm{~g}$ for males and $86-161 \mathrm{~g}$ for females were collected from ponds and stored in a 3,000 $\mathrm{m}^{3}$ concrete tank. Male broodstocks were injected with $17 \mathrm{a}$-methyltestosterone at the optimized protocol at $300 \mathrm{ng} / 100 \mathrm{~g}$ body weight at different injection frequencies, three times, four times, and five times at seven-day intervals. As a control, male broodstocks were injected with a saline solution to determine the spermatophore quality. Evaluation of the reproductive performance of the captive male was observed in the captive female broodstock tiger shrimp using artificial insemination. The weight of spermatophore $(0.041$ g), gonadosomatic index $(7.71 \%)$, the total number of spermatozoa $\left(64 \times 10^{6}\right.$ cells $/ \mathrm{mL}$ ) significantly increased, and the percentage of abnormal spermatozoa significantly decreased by $73 \%$ as well as hatching rate increased to $43.14 \%$ at the injection frequency of four times compared to the other treatments. In conclusion, injection of $17 \mathrm{a}$-methyltestosterone at the dosage of $300 \mathrm{ng} / 100 \mathrm{~g}$ body weight at the frequency of giving four times was effective enough to improve the reproductive performance of captive tiger shrimp. Therefore, the method proposed can be a strategy to produce better larvae and increase the income of the aquaculture business.
\end{abstract}

* Corresponding author. Tel.: +62-82344947171, e-mail: emirosmiati@yahoo.com 


\section{Introduction}

Tiger shrimp (Penaeus monodon) is still one of the essential fisheries commodities and is traded internationally. The increasing demand of the world market requires an increase in tiger shrimp production. To support the sustainable production of tiger shrimp, it needs quality broodstock with enough quantities for seed production (Wong et al., 2021). Until now, the provision of tiger shrimp broodstock for breeding still relies on mature wild broodstock. However, the availability of wild male broodstock has begun to be limited, depending on the season, and quality decreases (Wong et al., 2020).

Efforts to obtain captive male broodstock as an alternative to wild male broodstock have been made. Nevertheless, the captive male broodstock has not provided adequate results, such as poor spermatophore quality, which causes the broodstock to be unable to perform natural mating in a controlled pond or tank. The slow maturation of the captive male broodstock gonads is also the reason for low natural mating (Laining et al., 2016). Artificial breeding has been conducted to improve natural mating; however, hatchability was very low and, in some cases, even did not hatch. The low-quality spermatophores of captive male broodstock of tiger shrimp $P$. monodon are suspected to be a cause of unhatched eggs.

To improve the quality of the spermatophore of the male captive tiger shrimp, one of the things that can be done is to induce testosterone. Testosterone is a hormone produced by Leydig cells in the testes and plays an important role in spermatogenesis (Akbarinejad et al., 2017). The 17a-methyltestosterone (MT) is a synthetic androgen hormone derivative that has been widely used in aquaculture for masculinization, sexual inversion, and reproductive stimulation (Adenigba et al., 2017; Huang et al., 2019; Mordenti et al., 2017; Omeje et al., 2018; Passini et al., 2018; Wang et al., 2020). The use of MT in male $P$. monodon shrimp is to stimulate the formation and development of the testes in producing sperm. The utilization of MT to increase spermatogenesis and spermatozoa of wild male broodstock of tiger shrimp $P$. monodon and the spermatophore quality of male broodstock of white shrimp Penaeus vannamei have been reported by Alfaro, 1996. However, reports on the use of MT to improve the reproductive performance of the captive male broodstock of tiger shrimp $P$. monodon is still little and its use has not yet reached the production of nauplii. A previous study has reported that MT injection at doses of $300 \mathrm{ng} / 100 \mathrm{~g}$ of body weight as much as three times can improve the quality of captive male tiger shrimp but has not yielded significant results (Mulyaningrum et al., 2021).

The current study aims to evaluate the effects of different MT injection frequencies at optimized dose namely $300 \mathrm{ng} / 100 \mathrm{~g}$ body weight on the spermatophore quality and their effect on the reproductive performance of captive male broodstock of tiger shrimp $P$. monodon.

\section{Experimental shrimp}

\section{Materials and Methods}

Males and females tiger shrimp P. monodon were selected from traditional ponds in Takalar Regency and transferred to the hatchery of the Research Institute for Coastal Aquaculture and Fisheries Extension. The captive broodstocks had previously been free of the WSSV and AHPND based on PCR results. The shrimps were acclimated for one week in two 10-ton round concrete maturation tanks. During the rearing, the shrimps were fed three times a day with fresh feed (a combination of squid, sea worms, and shellfish) $15 \%$ body weight/day by dividing into three equal portions for the morning, afternoon, and evening feedings. Before feeding in the morning, uneaten food and debris were siphoned. The water quality parameters observed during the experimental period were salinity $30-32$ ppt, temperature $29-32{ }^{\circ} \mathrm{C}$, dissolved oxygen (DO) $5.5-6.08 \mathrm{mg} / \mathrm{L}$, and $\mathrm{pH} 7.88-8.25$ (APHA, 2005). At the same time, the depth of water was $50 \mathrm{~cm}$. Water exchange was performed about $80 \%$ per day using filtered and sterilized seawater. 


\section{Experimental design}

In this study, two experiments were conducted separately. The first experiment: the evaluation of different injection frequencies of 17a-methyltestosterone (MT)(Sigma-Aldrich Sweden AB, Stockholm, Sweden) to the reproductive parameters. The first experiment was to evaluate the effects of different injection frequencies of MT at the dosage of $300 \mathrm{ng} / 100$ $\mathrm{g}$ body weight (BW) on the survival, percentage of mature male broodstock, and spermatophore quality of captive male broodstock lasted 34 days. The first experimental design was a completely randomized design with four treatments and three replications consisting of three treatment groups and one control group.

The second experiment: artificial insemination using the optimized protocols from the first experiment. Since MT injection at the injection frequency of four times improved the quality of the captive male spermatophores (percentage of mature male broodstock, spermatophore weight, gonadosomatic index (GSI), total number of spermatozoa increased and percentage of abnormal spermatozoa decrease) and significantly different from the two treatment groups and control group, the injection frequency of four times at the dosage of $300 \mathrm{ng} / 100 \mathrm{~g} \mathrm{BW}$ was selected to evaluate the reproductive performance of the captive male broodstock using artificial insemination. The second experiment was designed to compare the control group (saline solution injection) to the two treatment groups (MT injection) without replication due to the limited maturation tank

\section{The evaluation of different injection frequencies of $M T$ in the reproductive parameters}

Males $(n=120)$ with an average weight of $54.81 \pm 3.96 \mathrm{~g}$ were randomly distributed into twelve 3-ton round concrete maturation tanks (10 shrimp in each tank) in the quarantine room adapted for a week. Before injection, male broodstock in each tank was tagged on the eyestalk for individual identification using plastic tags labeled. Shrimp was measured its BW to determine the dose of hormones and saline solution volume used according to the weight of the shrimp. The males were then electrically shocked using a transformer connected with two electrodes to release their spermatophores from terminal ampullae (Sandifer et al., 1984). A week after being given an electric shock, $1 \mathrm{mg}$ MT was dissolved in $10 \mathrm{~mL}$ alcohol $70 \%(100 \mathrm{ng} / \mu \mathrm{L})$. This MT solution was diluted until a final concentration of $2 \mathrm{ng} / \mu \mathrm{L}$. MT was administered to the male broodstock at an optimal dose of $300 \mathrm{ng} / 100 \mathrm{~g}$ body weight (BW) at different injection frequencies, namely; $A$. three times, B. four times, C. five times, and D. 0 (control) with a one-week interval. Males were injected with MT and saline solution in the second or third segment with a volume adjusted to the weight of shrimp using a syringe of $1.0 \mathrm{~mL}$. The volume of saline solution injected into the control was similar to the volume of MT administrated per $100 \mathrm{~g} \mathrm{BW}$ of the shrimp.

\section{Reproductive parameters}

Ten days after the last injection of each treatment, the surviving males were harvested, weighed, and removed their spermatophores using an electrical shock, as mentioned before. The survival rate (SR) was calculated using the following formulas: SR (\%) $=$ (No. of shrimp survived /No. of shrimp stocked) $\times 100$. Calculation of mature male broodstock (MB) was done on the surviving male broodstocks. The male broodstocks that released their spermatophores through electrical shock were expressed to be mature broodstock. (Prasetyo et al., 2017). The percentage of MB was calculated based on the following formula: MB (\%) = Number of male broodstock releasing spermatophores at the time of being given an electrical shock (shrimp)/No. of male broodstock given an electrical shock (shrimp) $\times 100$.

To determination of gonadosomatic index (GSI), the total number of spermatozoa (TS), and the percentage number of abnormal spermatozoa (AS), the spermatophore released from each gonopore after applying electrical shock was gently collected using sterile forceps and inserted into a $2.0 \mathrm{~mL}$ Eppendorf. Each spermatophore was weighed using an 
electrical balance (Sartorius, Germany) and noted to calculate the GSI. GSI (\%) = Gonad mass $(\mathrm{g}) /$ total body mass $(\mathrm{g}) \times 100$.

The spermatophore was homogenized manually with $1 \mathrm{~mL} \mathrm{Ca}{ }^{2+}$-free saline (Ca-F) in a glass tissue grinder (Radnoti, USA). Fifty $\mu \mathrm{L}$ of this tissue suspension was 10 -fold diluted with sterile Ca-F saline. Ten $\mu \mathrm{L}$ was aspirated into a pipette, placed on a hemocytometer, and covered with a coverslip. The spermatozoa were observed using a 40x objective microscope (Olympus DP2I, Japan). The spermatozoa were snapped, and its number was counted using the Image J software in six replicates. Spermatozoa with irregular body shape and incomplete spikes were expressed as abnormal spermatozoa (Jiang et al., 2009; Leelatanawit et al., 2014). The total number of spermatozoa (TS) and percentage number of abnormal spermatozoa (AS) were calculated using the following formulas: TS (cells $/ \mathrm{mL}$ ) $=$ Average total number of spermatozoa $\times$ dilution $\times 104$ cells $/ \mathrm{mL}$ while, AS $(\%)=$ Number of abnormal spermatozoa (cells $/ \mathrm{mL}$ )/Total number of spermatozoa (cells $/ \mathrm{mL}$ ) $\times 100$.

Determination of the gonad maturity stage of the male broodstock gonad qualitatively used histology analysis. A total of 5 males representing each group were randomly selected for histological analysis at the end of the study. Spermatophores were collected and separately fixed in a $10 \%$ neutral buffer formalin (Milton et al., 2018). After 24 hours, the preservative solution was altered with $70 \%$ alcohol for further processing. They were stained using hematoxylin-eosin before observing the gonad maturity stage using a microscope (Olympus DP21, Japan). The histological preparation procedure refers to the method described by Prasetyo et al. (2017).

\section{Analysis of reproductive parameters}

Analyses of Variance (ANOVA) were used to identify significant differences between the average value of each parameter (survival, percentage of mature male broodstock, spermatophore weight, gonadosomatic index, total number of spermatozoa, percentage of abnormal spermatozoa, and testosterone content). When significant differences were found, ANOVA was followed by Tukey's posthoc comparison test. All statistical analyses used IBM SPSS statistics software at a significance level of $\mathrm{P}<0.05$ (version 25). The correlation between spermatophore weight and the total number of spermatophore used IBM SPSS statistics software (version 25) with bivariate. The data were expressed as mean \pm Standard deviation (SD).

\section{Artificial insemination using the optimized protocols}

The healthy males $(n=50)$ with an average weight of $54.83 \pm 3.88 \mathrm{~g}$ and females ( $\mathrm{n}$ $=50$ ) with an average weight of $123.28 \pm 20.77 \mathrm{~g}$ were used for artificial insemination. Randomly selected broodstocks were transferred into two 10-ton round concrete maturation tanks (50 shrimp/tanks) with a male and female ratio of $1: 1$ and coded T1 (experimental group) and T2 (control group). This research was conducted without replication due to the limitations of the concrete tank. The males in T1 were induced with MT based on the optimized protocols resulted in the first experiment; that is, males injected $300 \mathrm{ng} / 100 \mathrm{~g} \mathrm{BW}$, and the males in T2 were induced with saline solution. The injection was done four times at one-week intervals.

\section{Artificial insemination}

Females who had just molted between 15 and 24 hours of postmolt were selected from the concrete tank and implanted with one spermatophore from the male either from $\mathrm{T} 1$ or T2. The female selected for implantation was placed on the ventral side table. Thelycum was opened using small cotton for ears. A fresh spermatophore was gently inserted into the thelycum cavity with forceps and index finger while irrigating shrimp with seawater continuously throughout the artificial insemination process. The female implanted spermatophore was then released into a separate trough of recovery or maturation. Two days post insemination, eyestalk ablation was performed on females to induce sexual 
maturation and continued with observing the gonad maturity stage. Observation of female gonad maturity stage used light aid from a flashlight to observe the ventral part of the shrimp. The female ovary would appear dark in cephalothorax to dorsal in the fifth segment near the tail: the older the ovaries, the darker and more extended. Females showing gonad maturity stage III or IV in the afternoon were transferred to the spawning tank. Previously, the spawning tank had been filled with $250 \mathrm{~mL}$ of filtered seawater, equipped with aeration, and closed for dark conditions. The female that had been spawned was removed from the spawning tank. The total number of eggs and the number of nauplii of each female was calculated using the sampling method by the following equation: Number of eggs $($ eggs/shrimp $)=($ Average number of eggs in sample/sample volume $) \times$ total amount of water in the bucket. Hatching rate $(\%)=($ Number of nauplii/number of eggs $) \times 100$ (Wen et al., 2020).

\section{Results}

\section{Reproduction performance and survival}

Percentage of mature male (MB), spermatophore weight (SW), gonadosomatic index (GSI), and total number of spermatozoa (TS) increased in all treatment groups ( $A, B$, and C). Percentage of abnormal spermatozoa (AS) decreased in groups A and B. In contrast, the AS increased in groups $C$. Survival (SR) increased in groups $B$ and $C$, while SR in group A did not increase. MB, SW, and GSI in group B were significantly higher than groups $A, C$, and $D(p<0.05)$. MB, SW, and GSI in groups $A$ and $C$ were significantly higher than groups $D(p<0.05)$. TS in groups $B$ was significantly higher than groups $A, C$, and $D(p<0.05)$. Also, TS in group $C$ was significantly higher than group $D(p<0.05)$ but was not significantly higher than group A $(p>0.05)$. TS in group A was not significantly higher than group $D(p>0.05)$. AS in group $B$ was significantly lower than group $A, C$, and $D(p$ $<0.05)$. AS in group $A$ was not significantly lower than groups $C$ and $D(p>0.05)$. SW, GSI, TS, and AS were the parameters of spermatophore quality assessed. SR in group B was the same as in group $C$ and was not significantly higher than groups $A$ and $D(p>$ 0.05). SR in group A was equal to in group D (Table $\mathbf{1}$ ).

Table 1 Reproductive performance and survival of the captive male broodstocks after 17amethyltestosterone and saline solution injection

\begin{tabular}{|c|c|c|c|c|}
\hline & \multicolumn{3}{|c|}{ 17a-Methyltestosterone (MT) injection } & \multirow{2}{*}{$\begin{array}{c}\begin{array}{c}\text { Saline solution } \\
\text { injection }\end{array} \\
\text { Control }(D) \\
\end{array}$} \\
\hline & Three times $(A)$ & Four times $(B)$ & Five times $(C)$ & \\
\hline Mean weight (g) & $55.5 \pm 1.5^{\mathrm{a}}$ & $54.1 \pm 1.4^{a}$ & $56.7 \pm 0.3^{a}$ & $54.2 \pm 1.4^{\mathrm{a}}$ \\
\hline $\begin{array}{l}\text { Percentage of mature male } \\
\text { broodstock }(\%)\end{array}$ & $51.1 \pm 15.4^{\mathrm{a}}$ & $79.4 \pm 18.0 b$ & $53.7 \pm 22.4^{a}$ & $49.7 \pm 25.8^{a}$ \\
\hline Spermatophore weight (g) & $0.031 \pm 0.02^{\mathrm{a}}$ & $0.041 \pm 0.02^{\mathrm{b}}$ & $0.029 \pm 0.02^{\mathrm{a}}$ & $0.019 \pm 0.10^{\mathrm{a}}$ \\
\hline Gonadosomatic index (\%) & $5.56 \pm 1.92^{\mathrm{a}}$ & $7.71 \pm 0.54^{b}$ & $5.18 \pm 0.21^{\mathrm{a}}$ & $3.51 \pm 0.72^{\mathrm{a}}$ \\
\hline $\begin{array}{l}\text { Total number of } \\
\text { spermatozoa (106 } \\
\text { cells } / \mathrm{mL} \text { ) }\end{array}$ & $31 \pm 4.93^{a b}$ & $64 \pm 6.03 c$ & $36 \pm 8.54^{b}$ & $18 \pm 2.64^{\mathrm{a}}$ \\
\hline $\begin{array}{l}\text { Percentage of abnormal } \\
\text { spermatozoa }(\%)\end{array}$ & $54 \pm 6.36^{b}$ & $27 \pm 9.18^{\mathrm{a}}$ & $62 \pm 9.22^{b}$ & $58 \pm 4.56^{b}$ \\
\hline Survival (\%) & $66.7 \pm 7.2^{\mathrm{a}}$ & $87.5 \pm 12.5^{a}$ & $87.5 \pm 12.5^{a}$ & $66.7 \pm 8.8^{a}$ \\
\hline
\end{tabular}

\footnotetext{
$*$ Values are mean \pm SD of quadruplicate groups. The values in the same row with different superscripts are significantly different $(p<0.05)$.
}

\section{Gonad histological examination}

Gonadal of the male broodstock in group $B$ had reached gonad with the $V$ gonadal maturation stage. Meanwhile, the gonadal of the male broodstock in groups $A, C$, and $D$ was in the IV gonadal maturation stage. The $V$ gonadal maturation stage had tubulus seminiferus starting to empty when spermatozoa come out of the tubulus seminiferous. The tubulus seminiferus in the $\mathrm{V}$ gonadal maturation stage appeared to have regressed. 
The IV gonadal maturation stage was characterized by the density of spermatozoa still seen in the tubulus seminiferous, although spermatozoa were already visible out of the tubulus seminiferous. Spermatozoa in group $C$ appeared to have more out of the tubulus seminiferous compared to groups A and D (Figure 1).

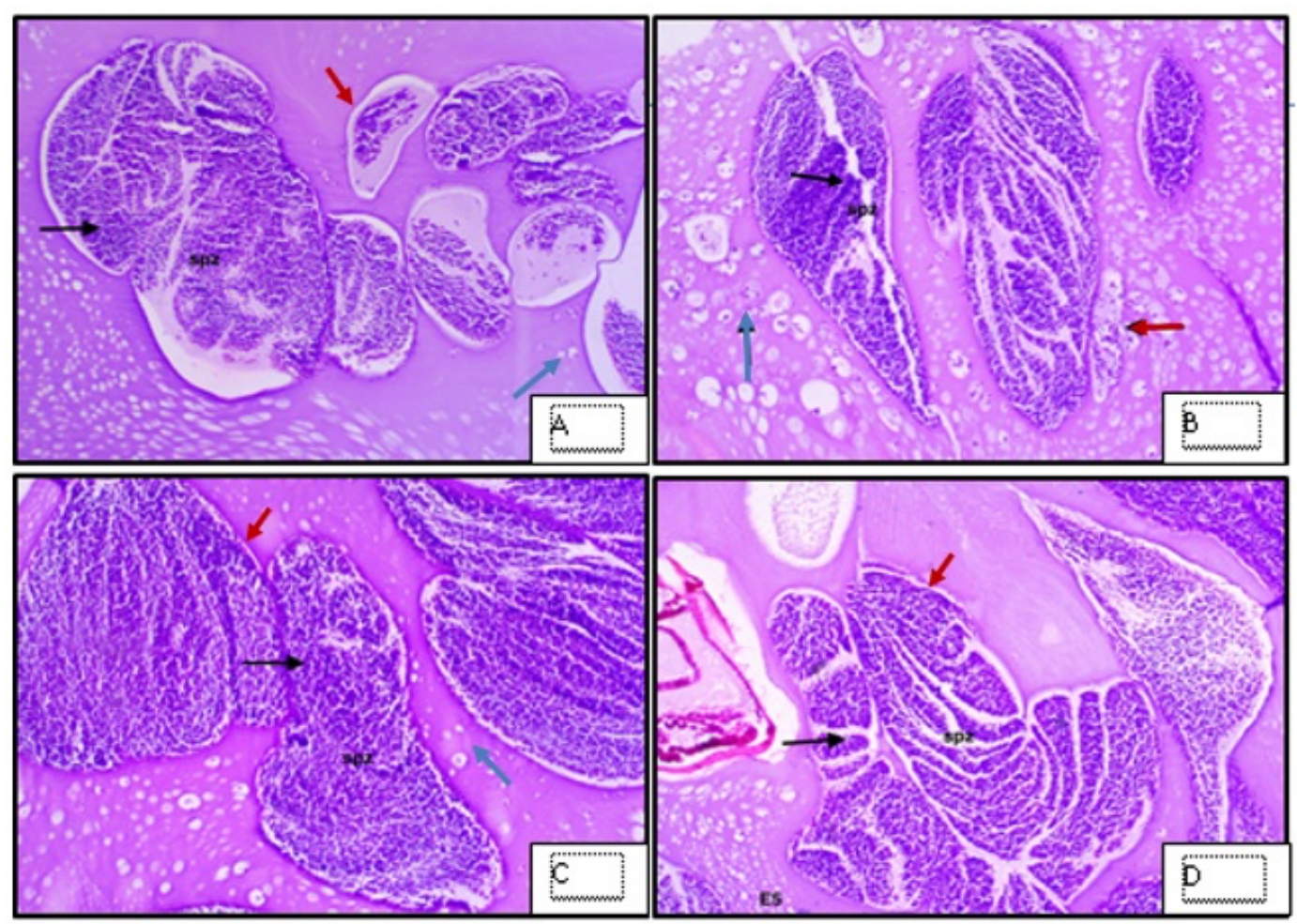

Figure 1 The gonadal histology of captive male broodstock in different gonadal maturity stages and treatments observed under a microscope at $400 \times$ magnification, the IV gonadal maturation stage in group $A, C$, and $D$, and the $V$ gonadal maturation stage in group $B, s p z=$ spermatozoa, black arrow = spermatozoa in the tubulus seminiferus, blue arrow = spermatozoa out the tubulus seminiferus, and red arrow $=$ tubulus seminiferus.

\section{Reproduction performance}

The number of females who successfully lay eggs from the T1 group was $100 \%$, while the T2 group was $80 \%$ lower than the T1 group. The number of eggs successfully harvested in the T1 group was higher than those harvested in the T2 group. Based on the results of egg hatching rates, it was found that no eggs released by females mated with males in group T2 hatched. In contrast, females mated with males in group T1 were matched by eggs released hatching with a pretty good hatching rate $(43.14 \%)$ (Table 2).

Table 2 Comparison of parameters between Test (T1) and Control (T2) groups of captive tiger shrimp P. monodon

\begin{tabular}{lll}
\hline & Test Group (T1) & Control group (T2) \\
\hline Male broodstock (g) & $69.96 \pm 13.56(\mathrm{n}=25)$ & $74.92 \pm 16.05(\mathrm{n}=25)$ \\
$\begin{array}{l}\text { Female broodstock }(\mathbf{g}) \\
\text { Number of spawning (shrimp) }\end{array}$ & $121.4 \pm 18.66$ & $125.1 \pm 21.09$ \\
$\begin{array}{l}\text { Number of eggs } \\
\text { (eggs/shrimp) }\end{array}$ & $288,951 \pm 89.58$ & $20(\mathrm{n}=25)$ \\
$\begin{array}{l}\text { Number of nauplii } \\
\text { (nauplii/shrimp) }\end{array}$ & $135,482 \pm 30.435$ & $235,514 \pm 105.92$ \\
Hatching rate (\%) & 43.14 & 0 \\
\hline
\end{tabular}




\section{Discussion}

The administration of MT at the different dosages at the injection frequency of three times did not affect the percentage of mature male broodstock and spermatophore weight but showed an effect on the sperm density of captive tiger shrimp $P$. monodon (Mulyaningrum et al., 2021). In the present study, the administration of MT at the dosage of $300 \mathrm{ng} / 100$ g BW shrimp at the different injection frequencies affects MB, SW, GSI, TS, and AS. The highest percentage of mature male broodstock was shown in the group $B$. The factor affecting gonad maturity and hormones was the shrimp's age (Mukti et al., 2020). The male broodstocks of tiger shrimp used in this study were more than 10 months old.

Injection of the testosterone hormone (MT, 17a-hydroxyprogesterone, testosterone propionate, and testosterone acetate) caused sperm quality in penaeid shrimp species to improve (Alfaro, 1996; Harlıoğlu et al., 2018). The application of MT in the common snook (Centropomus undecimalis) stimulated the development and growth of the testes and accelerated spermatogenesis (Passini et al., 2018). Furthermore, MT promoted the vitellogenesis of Anguilla japonica (Lai et al., 2018). Similar to the present study, MT induced a significant increase in spermatophore quality. The GSI advances the indicator of energetic transference between somatic growth and reproduction of shrimp (Feng, 2018). The highest GSI was found after the fourth injection. The development of spermatozoa productivity occurred after the third injection, and rapid development occurred after the fourth injection and decreased after the fifth injection. MT administration at the injection frequency of three, four, and five times, spermatozoa increased 2.6-fold (31 million), 3.6fold (64 million), and 1.7-fold (36 million), respectively. The increase in the number of spermatozoa obtained from administering MT at the injection frequency of four times was 3.8-fold compared to the three times the injection frequency reported by Mulyaningrum et al. (2021). The increase in the total number of spermatozoa obtained by MT injection four times was much higher than that of MT injection at a single dose of $0.1 \mu \mathrm{g} \mathrm{MT/} \mathrm{g} \mathrm{BW} \mathrm{white}$ shrimp Penaeus vannamei, which was only 3-fold higher than the control (Alfaro, 1996). In addition, the lowest percentage of abnormal spermatozoa was obtained in group $B$.

According to Alfaro (1996), testosterone is the primary androgen hormone in males and plays an essential role in the process of spermatogenesis (sperm production) and the expression of sexual behavior. GnRH promotes the secretion of LH by stimulating the pituitary gland. Then, LH promotes testosterone hormone synthesis by stimulating the testis's Leydig cells (Mukti et al., 2020). Naturally, the process of sperm maturation in fish is influenced by environmental signals that the hypothalamus will capture. The hypothalamus will instruct the work of organs under its influence (hypothalamic-pituitarytesticular (HPT) axis) to develop and ripen gonads by involving steroid hormones (testosterone and its derivatives)). This stimulation will activate GnRH (Gonadotropinreleasing hormone) cells so that the pituitary will actively produce GtH (gonadotropin hormone). GtH will activate Leydig cells to produce testosterone, 11-ketotestosterone, and 17,20-dihydroxyprogesterone which affect spermatogonia to produce spermatocytes $=>$ spermatids $=>$ spermatozoa. (Passini et al., 2018)

MT is a synthetic androgen hormone that must be provided with the correct management. The testosterone hormone injection at a high concentration of $10 \mu \mathrm{g} / \mathrm{g} \mathrm{BW}$ male tiger shrimp was able to produce spermatophores, but mortality was observed. Using a lower dose of testosterone hormone $5 \mu \mathrm{g} / \mathrm{g}$ BW can increase the mating success of the domesticated tiger shrimp (Maheswarudu et al., 2015). In the current study, MT injection had no significant effect $(p>0.05)$ on SR. However, the SR shown in groups $B$ and $C$ was higher than that in groups A and D. Administration of MT even provided up to $100 \%$ survival in white shrimp Penaeus vannamei at the dosages of 0.01 and $0.1 \mu \mathrm{g} / \mathrm{g}$ male (Alfaro, 1996).

Histology is one of the standard methods used not only to assess sex determination but also to determine the early stages of gonad differentiation. Kazemi et al. (2019) reported that androgenic hormones would increase during the final stages of sexual maturation in

fish and decrease after ovulation and spermion. Decreased concentration of androgenic 
hormones will affect the stage of gonad maturity. Like current studies, males injected by MT after the fourth injection were at the $V$ gonad maturity stage (full maturity) and then decreased at the IV gonad maturity stage after the fifth injection. Administration of MT hormone therapy was possible to shorten the hormonal cycle that occurs in male shrimp.

Previous studies have not reported the effect of MT use on the reproductive performance of captive male broodstock of $P$. monodon. However, the use of MT at higher doses of $1.0 \mathrm{mg} / \mathrm{mL}$ led to a significant increase in the number of egg masses per snail compared to controls not given MT (Rivero-Wendt et al., 2014). In this study, all-female broodstocks laid eggs after passing stage IV. Ovarian maturation was without reaching stage $V$. The cultivated shrimp broodstock was quite standard because it is relatively young and small compared to natural broodstocks. The captive male broodstocks used as a source of spermatophore after being injected with MT at a frequency of four times based on the results of histological analysis (Figure 1 ) has been in GML V (full maturity). One factor that influenced spawning in this study was the quality of eggs, good quality of spermatophores, nor both. According to Perez-Velazquez et al., 2001, sperm quality was an essential factor determining spawn, namely the ability to fertilize the egg. The presence of MT in sufficient quantities can improve reproductive performance in captive male broodstock of tiger shrimp $P$. monodon by stimulating androgenic glands and stimulating the $Y$ organ to tighten the molt cycle by reducing the duration of the molt cycle (Maheswarudu et al., 2015)

In conclusion, the injection of MT at different frequencies has an effect on the quality of spermatophores of captive broodstock of tiger shrimp $P$. monodon. The administration of MT improves the spermatophore quality and increases the number of eggs. The MT injection method at the optimized protocol, $300 \mathrm{ng} / 100 \mathrm{~g}$ body weight with a four-time injection frequency, seemed to successfully spawn eggs into nauplii that are not obtained in eggs from female brood mated males not given MT. The study investigated the feasibility of using optimal doses and delivery frequencies of MT in increasing seed production in the shrimp aquaculture industry.

\section{Acknowledgments}

The authors thank to the Ministry of Marine Affairs and Fisheries of the Republic of Indonesia for funding this research through SP DIPA-032.12.2.403828/2019. I am Rosmiati Rosmiati as the first author (main contributor) declared that two authors namely Andi Parenrengi and Emma Suryati are also the main contributors besides me who have helped in conceptualization, data curation, and writing-review \& editing and the others are member contributors for their contribution in data collection and data analysis.

\section{References}

Adenigba, I., Tumbokon, B. L., Serrano, A. E., 2017. Androgenic and anabolic effects of Pinus tabulaeformis carr. Pollen in Clarias gariepinus. Israeli Journal of Aquaculture Bamidgeh, 69(1388), 1-8. https://doi.org/10.46989/001c.21053

Akbarinejad, V., Tajik, P., Movahedin, M., Youssefi, R., 2017. Effect of extracellular matrix on testosterone production during in vitro culture of bovine testicular cells. Veterinary Research Forum, 8(1): 7-13. https://www.researchgate.net/publication/315069227

Alfaro, J., 1996. Effect of 17a-methyltestosterone and 17a-hydroxyprogesterone on the quality of white shrimp Penaeus vannamei spermatophores. Journal of the World Aquaculture Society, 27(4): 487-492. https://doi.org/10.1111/j.17497345.1996.tb00634.x

Feng, T., 2018. Spermatogenesis and sperm assessment in the black tiger prawn, Penaeus monodon. Ph.D. Thesis, University of Queensland, Australia.

Harlıoglu, M. M., Farhadi, A., Gür, S., 2018. Determination of sperm quality in decapod crustaceans.Aquaculture,490:185-193.

https://doi.org/10.1016/j.aquaculture.2018.02.031

Huang, M., Wang, Q., Chen, J., Chen, H., Xiao, L., Zhao, M., Zhang, H., Li, S., Liu, Y., Zhang, Y., Lin, H., 2019. The Co-administration of estradiol/17a-methyltestosterone 
leads to male fate in the protogynous orange-spotted grouper, Epinephelus coioides. Biology of Reproduction, 100(3): 745-756. https://doi.org/10.1093/biolre/ioy211

Jiang, S. G., Huang, J. H., Zhou, F. L., Chen, X., Yang, Q. B., Wen, W. G., Ma, Z. M., 2009. Observations of reproductive development and maturation of male Penaeus monodon reared in tidal and earthen ponds. Aquaculture, 292(2009): 121-128. https://doi.org/10.1016/j.aquaculture.2009.03.054

Kazemi, R., Yarmohammadi, M., Hallajian, A., Jalilpour, J., Mohammadi Parashkoh, H., 2019. Determination of sex and maturity stage of great sturgeon (Huso huso) using steroid sex hormones profiles, histology and laparoscopic images of gonads. Journal of Applied Ichthyology, 00: 1-10. https://doi.org/10.1111/jai.13948

Lai, X. J., Li, Z. Q., Xie, Y. J., Chen, S. X., Wang, Y. L., 2018. Androstenedione and 17amethyltestosterone induce early ovary development of Anguilla japonica. Theriogenology, 120: 16-24. https://doi.org/10.1016/j.theriogenology.2018.07.009

Laining, A., Usman, U., Syah, R., 2016. Induction of gonadal maturation of pond cultured male tiger shrimp, Penaeus monodon with different dosages of gonadotropin releasing hormone analogue against eye stalk ablation. Indonesian Aquaculture Journal, 11(1): 2330. http://ejournal-balitbang.kkp.go.id/index.php/iaj

Leelatanawit, R., Uawisetwathana, U., Khudet, J., Klanchui, A., Phomklad, S., Wongtripop, S., Angthoung, P., Jiravanichpaisal, P., Karoonuthaisiri, N., 2014. Effects of polychaetes (Perinereis nuntia) on sperm performance of the domesticated black tiger shrimp (Penaeus monodon). Aquaculture, 433(2014): 266-275. https://doi.org/10.1016/j.aquaculture.2014.06.034

Maheswarudu, G., Rajkuma, U., Sreeram, M. P., Chakravartyd, M. S., Sajeev, C. K,. 2015. Effect of testosterone hormone on performance of male broodstock of black tiger shrimp Penaeus monodon Fabricius, 1798. The Journal of Veterinary Science, 116(2015): 446456. http://eprints.cmfri.org.in/10384/

Milton, J., Bhat, A. A., Haniffa, M. A., Hussain, S. A., Rather, I. A., Al-Anazi, K. M., Hailan, W. A. Q., Abul Farah, M., 2018. Ovarian development and histological observations of threatened dwarf snakehead fish, Channa gachua (Hamilton, 1822). Saudi Journal of Biological Sciences, 25(2018), 149-153. https://doi.org/10.1016/j.sjbs.2017.03.011

Mordenti, O., Emmanuele, P., Casalini, A., Lokman, P. M., Zaccaroni, A., Di Biase, A., Parmeggiani, A., 2017. Effect of aromatable androgen (17-methyltestosterone) on induced maturation of silver European eels (Anguilla Anguilla): Oocyte performance and synchronization. Aquaculture Research, 1: 1-7. https://doi.org/10.1111/are.13475

Mukti, A. T., Sari, Y. G. P., Agusdinata, G. S. R., Satyantini, W. H., Mubarak, A. S., Luqman, E. M., Widjiati., 2020. The effects of laserpuncture on gonadal maturity and sperm quality of male striped catfish (Pangasianodon hypophthalmus). Theriogenology, 147: 102-107. https://doi.org/10.1016/j.theriogenology.2020.02.030

Mulyaningrum, S. R. H., Parenrengi, A., Lante, S., Tenriulo, A., Daud, R., Usman., 2021. Effect of different doses of 17a-methyl testosterone (17-a MT) hormone on male broodstock of tiger shrimp Penaeus monodon sperm quality. IOP Conf. Series: Earth and Environmental Science, 777(2021): 1-8. https://doi.org/10.1088/1755$1315 / 777 / 1 / 012024$

Omeje, V., Lambrechts, H., Brink, D., 2018. Effect of pawpaw (Carica papaya) seed meal on sex determination, growth, and survival, of Oreochromis mossambicus fry. Israeli Journal of Aquaculture - Bamidgeh, 70: 1-12. https://doi.org/10.46989/001c.20942

Passini, G., Sterzelecki, F. C., de Carvalho, C. V. A., Baloi, M. F., Naide, V., Cerqueira, V. R., 2018. 17a-Methyltestosterone implants accelerate spermatogenesis in common snook, Centropomus undecimalis, during first sexual maturation. Theriogenology, 106(2018): 134-140. https://doi.org/10.1016/j.theriogenology.2017.10.015

Perez-Velazquez, M., Bray, W. A., Lawrence, A. L., Gatlin, D. M., Gonzalez-Felix, M. L., 2001. Effect of temperature on sperm quality of captive Litopenaeus vannamei broodstock. Aquaculture, 198(3-4): 209-218. https://doi.org/10.1016/S00448486(01)00510-5 
Prasetyo, D., Laining, A., Sudrajat, A. O., 2017. Reproductive performances of wild male tiger shrimp Penaeus monodon post-injection of oocyte developer without eyestalk ablation. Jurnal Akuakultur Indonesia, 16(2): 193-204. https://doi.org/10.19027/jai.16.2.193-204

Rivero-Wendt, C. L. G., Borges, A. C., Oliveira-Filho, E. C., Miranda-Vilela, A. L., Ferreira, M. F. N., Grisolia, C. K., 2014. Effects of 17a-methyltestosterone on the reproduction of the freshwater snail Biomphalaria glabrata. Genetics and Molecular Research, 13(1): 605615. https://doi.org/10.4238/2014.January.28.6

Sandifer, P. A., Lawrence, A. L., Harris, S. G., Chamberlain, G. W., Stokes, A. D., Bray, W. A., 1984. Electrical stimulation of spermatophore expulsion in marine shrimp, Penaeus spp. Aquaculture, 41(1984): 181-187.

Wang, S., Lawless, J., Zheng, Z., 2020. Prenatal low-dose methyltestosterone, but not dihydrotestosterone, treatment induces penile formation in female mice and guinea pigs. Biology of Reproduction, 102(6): 1248-1260. https://doi.org/10.1093/biolre/ioaa035

Wen, W., Chen, X., Zhao, W., Yang, Q., Qin, J. G., Ma, Z., 2020. Evaluation of reproductive capacity in pond-reared Penaeus monodon after unilateral eyestalk ablation. Pakistan Journal of Zoology, 52(4): 1283-1289. https://doi.org/10.17582/journal.pjz/20190518040508

Wong, L. L., Chun, L. C., Deris, Z. M., Zainudin, A. A., Ikhwanuddin, M., Iehata, S., Rahman, M. M., Asaduzzaman, M., 2021. Genetic diversity and population structure of wild and domesticated black tiger shrimp (Penaeus monodon) broodstocks in the IndoPacific regions using consolidated mtDNA and microsatellite markers mtDNA and microsatellite markers. Gene Reports, 23(2021), 101047. https://doi.org/10.1016/j.genrep.2021.101047

Wong, L. L., Deris, Z. M., Igarashi, Y., Huang, S., Asakawa, S., Ayub, Q., Lim, S. Y., Ikhwanuddin, M., Iehata, S., Okamoto, K., Mariom, Asaduzzaman, M., 2020. Skimsequencing based genotyping reveals genetic divergence of the wild and domesticated population of black tiger shrimp (Penaeus monodon) in the Indo-Pacific Region. Biology, 9(277): 1-22. https://doi.org/10.3390/biology9090277 